\title{
THE MANAGEMENT OF THE UNIFIED SYSTEM OF CIVIL PROTECTION AT THE STATE LEVEL
}

\author{
Petro Gaman ${ }^{1}$, Mykola Andriyenko ${ }^{2}$, Vasyl Shoiko ${ }^{3}$ \\ ${ }^{1}$ Doctor of sciences (Public Administration), associate professor, Ukrainian Research Institute of Civil \\ Protection, Kyiv, Pavlo Tychyna Uman State Pedagogical University, Uman, Ukraine, e-mail: \\ petro185@ukr.net, ORCID ID: https://orcid.org/0000-0002-3239-8936 \\ ${ }^{2}$ Doctor of sciences (Public Administration), associate professor, head of the center for civil \\ protection, Ukrainian research institute of civil protection,Ukraine, e-mail: andnv@ukr.net, ORCID \\ ID: https://orcid.org/0000-0002-9222-4831 \\ ${ }^{3} \mathrm{PhD}$ (History), associate professor, deputy chief, Ukrainian research institute of civil protection, \\ Ukraine, e-mail: pom_mtz@ukr.net, ORCID ID: https://orcid.org/0000-0001-8670-8779
}

\begin{abstract}
According to the Constitution, every citizen has the right to protection of his life and health from the consequences of accidents, catastrophes, natural disasters, the use of weapons and the requirement to guarantee the exercise of this right from the Executive authorities, heads of enterprises, organizations and institutions, regardless of ownership and subordination. The state as a guarantor of this right should create and develop a unified state system of civil protection (CP), this includes civil defense and protection of the population and territories from emergency situations (ES) of technological and natural character. It is advisable to pay attention to the fact that the state of any society depends on the level of public administration, therefore, according to many politicians, scientists and public figures, the problem of efficiency comes to the fore. This statement is especially important for Ukraine. The solution to this problem is a pledge and a necessary condition for solving all other problems of the Ukrainian society, which is experiencing a systemic crisis of management. Fundamental importance is a significant deepening of fundamental theoretical and methodological research of public administration, the creation of a developed theoretical framework implemented in scientific theories, concepts and projects. Over the past 15 years, more than 5.8 thousand classified emergencies have been registered in Ukraine, in which more than 34.1 thousand people have suffered, more than 6.7 thousand of them have died, and direct material losses amount to more than 30 billion. UAN. The process of formation of the organizational structure of management of the civil protection system requires a clear choice of the necessary methods, techniques, technologies, stages (steps) and etc. Generalization of existing approaches to the creation of a universal methodology aimed at the development and evaluation of the formed management decisions of the scheme formation of the organizational structure of project portfolio management in the system of civil protection of Ukraine. This method of formation of a new organizational structure of the civil protection system should be based on archival data and indicate that under the influence of the external turbulent environment, the solution of new problems can be solved by taking into account information-related cause-and-effect relationships. Thus, the study in the direction of the formation of a new structure in the management of the civil protection system at the state level is extremely relevant.
\end{abstract}

Keywords: mechanism, public administration, civil protection, state security, organizational structure, principles of public administration of the civil protection system.

JEL Classification: H19

Formulas: 0; fig.: 0; tabl.: 0; bibl.: 15 .

Introduction. In modern geopolitical and security conditions, hybrid wars, non-violent methods of struggle, terrorism, mass migration of the population, the use of high-precision weapons, as well as weapons on new physical principles (geophysical, meteorological, genetic, etc.) become a serious 
challenge for the systems of ES and CD. However, institutional, structural and legislative changes in these systems as an adequate response to the spread of the relevant threats occur at best, with significant and insufficient intensity.

The domestic system of emergency situations, as well as similar systems of many foreign countries, is functionally focused mainly on the adoption of measures to eliminate the consequences of man-made and natural disasters. As for the institutional problems of the development of the state system of the emergencies, it should be noted that despite the numerous reforms aimed at the structural and functional modernization of the $\mathrm{CD}$ system, the latter was de-jure eliminated in 2013. At the same time, the process of creating the unified state system of civil protection (USS of $\mathrm{CP}$ ) still not completed due to the imperfection of the current legislation, as well as state and other institutions involved in the implementation of public policy in the field of civil protection.

The urgent need to increase the level of protection of the population, territories, cultural and material values, the environment and other objects from emergencies, as well as the scientific and practical justification of ways to improve the institutional framework for the development of the USS emergency situations require the identification of factors, causes and prerequisites that negatively affect the stability of the functioning of this state system [1].

An important component on the way to the gradual development of the USS of CP is also the generalization and grouping of the relevant factors, the identification of relationships between them, because without this it is not possible to ensure the effective implementation of a set of measures to neutralize or minimize their effects.

Literature review. It should be noted that certain events and processes that negatively affect the process of formation of the institutional foundations of the functioning of the domestic system of $\mathrm{CP}$ were covered in the literature by such scientists as M. Andrienko, D. Biryukov, V. Grechaninov, L. Zhukova, N. Klimenko, O. Kuzemin, S. Kuznychenko, O. Leshchenko, S. Mosow, S. Marova O. Ostroverh, A. Romin, G. Sytnik, V. Cage, V. Tishchenko and others.

Scientists and practitioners focus mainly on the functions and tasks of the state systems of the $\mathrm{CP}$, their organizational structures, specific mechanisms for the implementation of certain activities of the $\mathrm{CP}$ at various administrativeterritorial levels. At the same time, the impact of globalization processes on the formation and functioning of the state systems of $\mathrm{CP}$ is insufficiently investigated [2].

Aims. Aims is to investigate scientific approaches to the management of the unified system of civil protection at the state level.

Methods. The author used the methods of static and logical comparison, systematization and generalization, which made it possible to achieve the goal of the study.

Results. The general disadvantage of previous studies of domestic scientists on this issue is the fragmentary nature of the scientific results obtained by the authors on various problems of the functioning the USS of CP: political, 
legal, institutional, organizational, etc., which does not allow to make a more or less complete picture of this problem.

From the standpoint of organizational and functional analysis, the system of public administration of civil protection is an integral part of the system of public administration, since national interests, as well as threats to their implementation, are present in all spheres of public activity. Therefore, the principal feature of the system of public administration of civil protection is that it seems to be "immersed" in the general system of public administration [3].

Taking into account the above, the main tasks of the USS of CP mainly correspond to such direction of state policy as "protection of population and territories from emergency situations of natural and man-made character". With the key tasks of the CD, the tasks of the USS of CP overlap only partially. The boundaries and contours of the sphere of science and practice of public administration - "civil protection" in Ukraine is quite blurred, which, among other things, determines the infantile state of the institutional foundations of the development of the USS of CP and directly affects the level of protection of CP objects from natural, man-made and other threats.

The system of public administration in the field of civil protection has a powerful influence on the direction, content and effectiveness of administrative, political, socio-economic and other types of public administration as a result of the strategic importance of power management decisions for society and the state, especially in conditions when there is a rather acute question of neutralizing threats to vital interests. This means that the functions of the system go, for example, beyond the administrative-political or socio-economic sphere of public administration [4].

Taking into account the above, the system of public administration of civil protection is a set of interdependent, interacting bodies of public administration and senior officials of the state, which, within the framework of the current legislation and with the involvement of the state potential (material, financial, intellectual and spiritual) at its disposal, develops and implements power, regulatory, coordinating, regulatory and regulatory state management impacts (decisions) on security facilities in order to predict, timely identify, prevent and neutralize threats to the sustainable development of the above - mentioned facilities, first of which lives in the national interests.

The group of standards, which is included in the set of national standards in the field of CP, includes: standards of requirements for monitoring, prevention and elimination of emergency situations, protection of population, animals, plants, economic objects, soil protection, air, food, food raw materials and feed, water sources and water supply systems, means and methods of management, communication and warning, technical equipment of rescue units, special protection [5].

It is worth noting that the basic principles serve as the basis for the public administration of the civil protection system. According to the current legislation of Ukraine, civil protection operates on the following principles: 
- Guarantee by the state to citizens of the constitutional right to protection of life, health and their property, and to legal entities-the right to safe functioning;

- Voluntary involvement of people in the implementation of activities in the field of $\mathrm{CP}$ related to the risk to their life and health;

- An integrated approach to solving the problems of CP;

- Creation of system of rational preventive security with the purpose of highest possible, economically justified reduction of the probability of occurrence of emergencies and minimizing their consequences;

- Territoriality and functionality of the unified system of civil protection;

- Minimization of harm to the environment;

- Publicity, free access of the population to information in the field of CP in accordance with the legislation [6].

Globalization has a direct impact on the development of the state and society, in particular on the functioning of public administration systems, almost all scientists who study this problem note. At the same time, as most experts who critically evaluate the processes of globalization rightly note, in this phenomenon there are more negative consequences for the formation of national forms of statehood than positive ones.

Management in the field of civil protection is closely connected with the provision of security in emergency situations, because emergency situations as a threat to the safe state are independent components of many dangers. Emergency situations may be accompanied by terrorist acts, explosions, traffic accidents, transport accidents, industrial processes, natural hazards, illegal human activities. Ensuring security in emergency situations is associated with the implementation of a wide range of legal and special organizational and technical measures to streamline public relations, in particular, the establishment and maintenance of the legal regime of the emergency zone. This regime is implemented in various organizational and legal forms and by various methods [7].

Additionally, the composition of the institutional foundations of the state of the Central locking system can distinguish two interconnected block elements:

1. Institutional unit (infrastructure component):

- subsystems (branch and territorial);

- subsystem links;

- public authority;

- local government;

- other subjects of providing CP: officials, structural units, subsidiary bodies (coordination, Advisory, etc);

- CP forces (emergency services, formation, etc);

- legal entities (business entities and non-profit organizations).

2. The legal Department (legal component):

- Constitution (Basic Law of the state);

- international treaties of Ukraine; Constitutional Laws; 
- the main Laws regulating the legal regime of the state system of CP;

- basic (status) laws that determine the legal status of the subjects of securities;

- by-laws and regulations on the activities of the subjects of the CP: acts of the executive authorities and the local government.

The history of the development of the functions of the state in the national Assembly from ancient times to the present day convincingly proves that it is the institutions (governing bodies, forces, etc.) and legislation that are the core elements formed by society and the state in order to most effectively ensure their own protection against various threats associated with the risk of various emergencies [8].

Measures of administrative coercion are actively applied, which significantly limit the rights of citizens not only on grounds related to illegal behavior of people, but also for other reasons. This may be the consequences of emergency situations: radioactive or chemical pollution, significant destruction of infrastructure to ensure the life of the population and enterprises.

Therefore, the main focus of the office should be on the development of a set of activities that can destroy the mechanism that blocks the possibility of effective action. Given this, it is important to study the factors and develop ways and methods of crisis management, with the basic rules should be:

- systematic analysis of the situation and decision-making; early preparation of an emergency plan adapted to local conditions and its timely clarification;

- constant risk assessment and development of measures to minimize possible damage (losses) on this basis);

- continuous testing of the ability of specially created organizational, technical, information and other systems to immediately enter the operating mode;

- timely provision of the highest level of information management and provision of comprehensive information to the population and the media;

- timely detection of mistakes and immediate adjustment of actions; organization of effective interaction of local authorities; monitoring and forecasting of risks and dynamics of the situation.

Discussion. Public administration needs to be seen as a complex dynamic system with many parameters. The system of support is an interconnected and mutually summarized set of relevant organizational structures, forces, means, as well as certain procedures (rules) for the formation and implementation of management decisions aimed at ensuring civil protection as a component of national security [9].

Public administration in the field of civil protection is a specific type of public administration that covers socio - economic, cultural and political and other spheres of public life. The functions, powers and responsibilities that are assigned to it are specific, since the main purpose of management actions is primarily timely forecasting, identification, prevention and neutralization of real and potential threats (with the involvement of appropriate, specially created forces and means), which simultaneously concern the interests of each person, social group, society and the state, therefore, is a priority management problem, 
the solution of which is assigned to the relevant system [10]. Ultimately, the management impact is aimed at ensuring the conditions under which the sustainable progressive development of society and the implementation of national interests in all spheres of state life can take place. Therefore, the system is characterized by features and characteristics of both inter-sectoral and functional components of public administration, which, of course, has a significant impact on the functions, forms, methods and methods of public administration in this area.

Management in the field of civil protection can be defined as a special kind of activity of state and non-state actors to streamline the security system ensure its optimal functioning and sustainable development of the organization of management of the national security system [11].

The security of the state depends on the effectiveness of management decisions. Therefore, the formation and functioning of the system of public administration in the field of civil protection can be divided into several structural levels. It is also fundamental that, like any social system, the system of public administration in the field of civil protection has a complex structure. But in any configuration it should always be the highest strategic (institutional) level. At this level, the most important political decisions are made, which are reflected in the relevant laws, concepts, strategies, etc.

The main mechanisms of public administration of the civil protection system is the state standardization, certification, examination, state supervision and control of compliance with the requirements in the field of $\mathrm{CP}$, licensing, accounting and implementation of the requirements of $\mathrm{CP}$ (CD), as well as insurance and economic regulators (taxes, fines, sanctions for damages, funds, benefits and the like) [12].

It should be noted that the mechanism that performs systematic monitoring and control over the objects, processes and systems of protection, prediction of zones and consequences of probable emergencies, the state of implementation of preventive measures to reduce their scale, collection, processing, transmission and storage of this information is monitoring.

Monitoring should be carried out using many methods and means on the principle of maximum involvement of the existing organizational structures of the subjects of monitoring of technogenic and environmental safety and emergencies.

For example, monitoring and forecasting of initial events initiating hydro meteorological emergencies is carried out by the agencies of the HMS, which also monitors the state and pollution of the atmosphere, water and soil. Seismic observations and prediction of earthquakes in the country is carried out by a system of seismic observations and earthquake prediction, which includes institutions and observation systems of the National Academy of Sciences, the Ministry of defense and Gosstroy [13].

In addition, for our country, which has faced unprecedented challenges of a military and political nature in its recent history (the annexation by the Russian 
Federation of the territory of Crimea and the occupied territories of Donbass by the Russian Federation), the solution of problems related to the construction of an effective state system of the state in the context of globalization, without exaggeration, and one of the primary and most important steps towards the preservation of its statehood, sovereignty and territorial integrity.

For Ukraine, the full integration of subjects of such national monitoring into a single system, the development of a unified methodology for the collection, accumulation and transfer of monitoring information remains a problem. And it is the construction of an effective mechanism of public administration of the civil protection system that will significantly improve the effectiveness of monitoring and obtain a significant effect from monitoring emergency situations by reducing the time to prepare for the response and elimination of their consequences, as well as by obtaining objective data for planning.

The system approach allows us to consider the mechanism of public administration in the field of civil protection in the unity of its components of the first and second levels, which are inextricably linked with the external environment. He considers a complex organization as a system consisting of a certain number of interrelated subsystems and mechanisms, allows determining the purpose of each of them in the context of a common goal, to formulate tasks that require solutions for each of these subsystems. It should be noted that the distribution of the system of public administration in the field of civil protection on subsystems and elements can be carried out on the basis of other aspects of its functioning: on a territorial basis, levels of response to emergencies, industry, modes of operation, major activities, or organizational structure, the use of certain mechanisms of state influence on the prevention and overcoming of the consequences of accidents, disasters, natural disasters and other crisis situations, which will be the subject of further research [14].

Their peculiarity is that they are most closely intertwined with political and public administration. And it is at this level that the General state policy, its conceptual framework and the main tasks for its implementation are determined. Given the above is quite logical is the formula proposed by G. Sytnik:" the process of making management decisions in the field of security is a consistent and trivial processing of information blocks: data - situation goal - choice " [15].

The main focus of the office should be on the development of a set of activities that could destroy the mechanism blocking the possibility of effective action.

The solution to the problems of natural and man-made security of Ukraine is provided by the state level of such activities:

1. Management of technogenic risks, which will ensure a sustainable, guaranteed reduction in the number and consequences of man-made and natural emergencies. 
2. Creation of an integrated interdepartmental system of monitoring and debugging of the state service for forecasting and prevention of natural and manmade emergencies.

3. Creation of a national register of potentially dangerous objects and territories and mechanisms for their monitoring.

4. Improving the efficiency of state supervision over the state and functioning of potentially hazardous industries.

These measures are implemented through certain mechanisms of public administration of the civil protection system.

The mechanism of public administration of the civil protection system is the application of measures of influence of the subject of public administration to prevent and overcome the consequences of emergency situations, ensuring the necessary level of technological and environmental safety and the implementation of the goals and objectives set for society in the field of human security and society as a whole.

The main mechanisms of public administration of the civil protection system is the state standardization, certification, examination, state supervision and control of compliance with the requirements in the field of $\mathrm{CP}$, licensing, accounting and implementation of the requirements of $\mathrm{CP}$ (CD), as well as insurance and economic regulators (taxes, fines, sanctions for damages, funds, benefits and the like).

Thus, it is necessary to weigh the importance of civil protection as a component of national security and to make appropriate changes in legislation and regulations. In particular, consider the possibility of creating a structural unit in the office of the national Security Council of Ukraine, which will directly deal with civil protection issues in the country and the subcommittee of the Verkhovna Rada on civil protection, which will systematically implement legislative policy in the relevant field. The management policy has a clear structure. The above allows us to conclude that the concept, doctrine and strategy play a crucial role in the development and implementation of public administration policy in the field of civil protection.

Conclusion. Thus, the analysis of the basic principles of management in the field of civil protection leads to the conclusion that there is a need to allocate civil protection as a separate component of national security and its management. This problem is complex, and its solution will contribute to the improvement of administrative and legal regulation of legal relations in the field of civil protection, strengthening of legal, scientific, technical and resource base, improvement of public administration in this area. The acuteness of this problem requires urgent measures on the part of the subjects of law-making and law enforcement. The strategy of activity of subjects of public administration in the field of civil protection will be aimed at achieving the advanced world level of protection of the individual, society and the state from emergency situations and their consequences. 
In the context of globalization, the state systems of CP should be very sensitive to changes in indicators (indicators) for assessing the state of threats and dangers in various spheres of public life and public administration. It is very promising to widely introduce into anti-crisis practice methods of forecasting and monitoring of emergencies of different nature, preventing them in their natural States, as well as the development and implementation of practically oriented methods of risk management. The management and force of the civil protection should be financially and technically self-sufficient and tactically mobile, make greater use of inter-Agency coordination and communication mechanisms, and research institutions, analytical units and structures should make greater use of information management practices and better civil protection practices.

Author contributions. The authors contributed equally.

Disclosure statement. The authors do not have any conflict of interest. References:

1. Lipkan, V. A. (2002), "Object, subject matter and structure of national science", Pravo i bezpeka, vol. 4, pp. 26-29.

2. Bychenok, M. M. (2008), Ryzyky zhyttiediialnosti u pryrodno-tekhnohennomu seredovyshchi [Risks of vital activity in natural-technogenic environment], Instytut problem natsionalnoi bezpeky Rady natsionalnoi bezpeky i oborony Ukrainy, Kyiv, Ukraine, p. 160.

3. Lipkan, V. A. (2003), "The concept of national security system of Ukraine", Pravo i bezpeka, vol. 2, pp. 57-60.

4. Rak, Yu. P. (2011), "Theoretical approaches to the design of information automation systems for project-oriented management", Upravlinnia proektamy ta rozvytok vyrobnytstva, vol. 1, pp. 433-438.

5. Averianov, V. B. Tsvietkov, V. V. and Shapoval, V. M. (1998) Derzhavne upravlinnia: teoriia i praktyka [Public administration: theory and practice], Yurinkom Inter, Kyiv, Ukraine, p. 432.

6. Maslov, Ye. P. "Derzhavna polityka u sferi tsyvilnoho zakhystu Ukrainy $v$ umovakh nadzvychainykh sytuatsii", available at: www.zerkalov.kiev.ua.

7. Holovatyi, M. (2015), "The state and society: The conceptual foundations and social interaction in the context of formation and functioning of states", Economic Annals-XXI, 9-10, pp. 4-8.

8. Marova, S. F. (2009), Upravlinnia bezpekoiu zhyttiediialnosti [Management of life safety], Veber, Donetsk, Ukraine, pp. 342.

9. Bychenok, M. M. (2005), Osnovy informatyzatsii upravlinnia rehionalnoiu bezpekoiu [Fundamentals of Regional Security Management Informatization], Kyiv, Ukraine, p. 194.

10. Marova, S. F. (2006), "Sustainable development concept for the region: directions for implementation", Menedzher, vol. 3(37). pp. 163-169.

11. Orlov, O. V. (2010), "System approach to the definition of the conceptual apparatus of the field of science "public administration"”, Teoriia ta praktyka derzhavnoho upravlinnia, vol. 2 (29), pp. 18-24.

12. Ortseva, O. S. (2013), "Mechanisms of public administration: theoretical approaches to the definition of the concept", available at: http://www.confcontact.com/2013specproekt/gu2_ortseva.htm.

13. Radchenko, O. V. (2009), "Category "mechanism" in the system of public administration", available at: http://archive.nbuv.gov.ua/portal/soc_gum/dtr/du/2009_3/files/DU309_14.pdf.

14. Tyshchenko, V. O. (2010), "Main tendencies of development of the state policy in the field of civil protection of Ukraine", Naukovyi visnyk akademii munitsypalnoho upravlinnia, vol. 4, pp. 356-366.

15. Sadkovyi, V. P. Romin, A. V. and Ostroverkh, O. O. (2013), Derzhavne upravlinnia u sferi tsyvilnoho zakhystu $v$ Ukraini: normatyvno-pravovyi aspekt [Public administration in the field of civil protection in Ukraine: regulatory and legal aspect], TOV “Oberih", Kharkiv, Ukraine.

Received: Decemder 18, 2019 